\title{
Technocratic Structures of Climate Policy: Dead-end Debates, Neat Narratives and Manipulative Machiavellianism
}

\author{
Taylor A. Murray \\ School of Geography and the Environment, University of Oxford \\ South Parks Road, Oxford, OX1 3QY, United Kingdom \\ Tel: +44 (0)1865 285070 E-mail: tayloramurray@ymail.com
}

Received:November 19, 2012 Accepted:December 15, 2012 DOI:10.5296/jpag.v2i4.2800

\begin{abstract}
Contemporary models of climate change policy-making in the United States are proving unproductive. The increased role for experts and expert-led policymaking is unprecedented. However this power has been paradoxical. This paper argues that an excessive role for science in discussions of climate change has diminished the public's role, and has thus undermined the efforts on behalf of policymakers to pass comprehensive climate change policy. Two main aspects of the excessive role for science in the formation of climate policy were found to be 1 . the large influence of dissenting scientists on the debate, and 2. the alienation of the public from the discourse. Further, possible scenarios for policymaking, which better balance the roles of experts, the public, and policymakers, are discussed and frameworks for the future are outlined.
\end{abstract}

Keywords: Post-normal Science, Climate Change, Public Policy 
1. Introduction

The environmental movement in the United States in the 1960s and 1970s was one of the most successful popular movements in U.S. history. Public engagement in the formation of environmental policy during this period helped enact a mélange of historic environmental laws, or "epic victories" (Shellenberger \& Nordhaus, 2004, p.8). The movement's success was due in no small part to the public's prominent role in policy discourse. Environmental advocacy was so common among the public that it became a largely bipartisan issue conservative administrations went on to pass some of the country's most stringent environmental law. Today, the political milieu surrounding U.S. environmental law is much different. The complex nature of contemporary environmental issues like climate change seemingly mandates an increased role for experts in policy discourse. However, this paper argues that an excessive role for science in discussions of climate change has undermined the public's role, and has thus hamstrung the passage of climate change policy in the U.S. Two main aspects of the excessive role for science have frustrated the formation of climate policy: 1. the large influence of dissenting scientists on the debate, and 2. the alienation of the public from the discourse.

The technocratic model of climate policy formation in the U.S. which relies heavily on expert scientific opinion to inform policy and policymakers, and struggles to engage the public, has magnified the debate about the science of climate change. Because the technocratic system puts so much emphasis on "expert" opinion, those opposing climate policy have found it effective to propagate the views of a small minority of scientists whose findings contrast with the mainstream scientific consensus; this creates a pseudo debate regarding the science that forms policy. Thus, rather than arguing about our different ideas of science, risk, and monetary commitment in the proper policy discourses, the debate has been transformed into one about whether there is, in fact, even an issue. If the scientific information that underpins policy appears to be less settled, it is difficult to form policy.

Furthermore, a technocratic form of policy making in the U.S. has hampered the nation's ability to pass policy to address climate change because it disengages the public from policy discussions. The public's lesser role in policy discourse diminishes its ability to act as an intermediary between science and policymakers. In order to pass effective climate policy, climate science and the general public must take on roles which balance one another without balance, neither can function to inform policy in a valuable way. To achieve this balance, more decision makers and members of the general public are needed to be critical judges of scientific knowledge and gain awareness of how cultural tools mediate action.

\section{Technocracy}

Technocratic models of climate science give science too much authority in the policy sphere. Even though mainstream, peer-reviewed science is a valuable voice in discussions of climate change, an excess of science undermines the public's role and exacerbates a dysfunctional policy discourse. The public role has become confined by a perception of conflicting opinions in the scientific community. This helps reshape the contribution of science into a host of hybrid political/scientific battles over different ideas and interpretations of science. 
Technocracy has led science to take on such anomalous roles in the political sphere that science has entered a "post-normal" era, where the old dichotomies of "fact" and value, and scientist and politician, have been transcended (Funtowicz \& Ravetz, 1993, p. 739). In February of 2012, climate scientist Peter Gleick, Chairman of the Task Force on Scientific Ethics and Integrity of the American Geophysical Union, obtained and distributed - under a false name - documents outlining a political campaign of the Heartland Institute, a conservative anti-environmentalist think tank, to distort mainstream climate science in U.S. elementary schools. By giving science so much authority, technocratic forms of science allow dissident, value-laden forms of science to affect perception. The increased role of this type of science has caused mainstream scientists to often find themselves involved in political battles over science.

Science possesses characteristics which should limit its use in climate policy discussions. Climate science faces a number of irreducible uncertainties that are veiled to other actors in a technocratic model. Irrespective of its value, science can't define objective and certain truth for us. However, it can provide very high levels of certainty to its findings. Yet technocratic models of science proceed as if science has the ability to be absolutely certain and to determine "fact," or "objective truth." By highlighting inherent uncertainties, contrarians exploit any misunderstandings of scientific truth. Technocracy allows political actors opposing climate policy to decry the inherent uncertainties of the science which are incongruous with their positions; as if (the always elusive) scientific certainty should be achieved before policy is warranted. Notions of truth are thus treated as political accomplishments rather than reflections of exogenous reality (Lahsen, 1999, p.138). If the public, policymakers, and science experienced more clearly defined, balanced roles, the public and policymakers could engage in a fitting value-laden debate of policy based on the realities of science and its uncertainties. Yet the (pseudo) debate is still stuck on the existence of the issue, arguing over claims of truth. Thus, the technocratic authority given to climate science contributes to the stagnation of policy decisions.

The lay public often finds it difficult to engage in policy discussions of climate change because it has difficulty communicating with expert science. The Intergovernmental Panel on Climate Change (IPCC) epitomizes a technocratic body of science that struggles to communicate its message. The IPCC is an unprecedented scientific body, made up of thousands of the world's most credentialed climate change scientists. The IPCC was designed specifically as a basis for politicians to construct climate policy (Oreskes, 2007, p.67). The IPCC releases assessment reports crafted and reviewed by an exclusive group of scientific experts. The National Oceanic and Atmospheric Administration of the United States has hailed the IPCC as the "the most senior and authoritative body providing scientific advice to global policy makers" (NOAA, 2008, p.1). Although the IPCC may succeed in providing some advice to policy makers, the highly technical and esoteric nature of reports creates a communication barrier between climate science and the public. In May of 2011, the IPCC launched a "Communications Strategy," which outlines, among other things, its efforts to better communicate with the public (IPCC, 2011). Unintentionally poignant, it demonstrates 
that the IPCC is a technocratic engine of science that struggles to communicate with the public.

\section{Discourse, Narratives, and Mediated Means}

Models of climate change science influence actors by utilizing certain cultural tools which help frame the issue. A cultural tool, or a narrative of the issue, mediates the behavior of actors in the policy sphere: how we perceive an issue dictates how we act in relation to it. By using scientific language and formatting information in a certain way, actors can create a "narrative" and frame perception". The framing of climate change thus has the ability to effectively influence how the issue is addressed. As technocracy grants science such compelling authority in discussions of policy, the scientific narrative is especially powerful.

The technocratic model of climate science allows political actors to interpret and use science in ways that agree with their values and beliefs. Instead of using science as a valuable source of autonomous information to inform action, actors in the discourse have constructed different scientific narratives that are highly influential. Because scientific "fact" is given so much authority in this system, it leaves, in effect, a vacuum of public mediation in discussions of climate policy. Politics, it seems, abhors a vacuum. A leaked document earlier this year outlined how organizations opposed to climate policy have launched campaigns in American K-12 schools which seek to make the mainstream scientific underpinnings of climate change appear to be less established (Goldenberg, 2012, p.1). The campaigns formed narratives which contested scientific "truth," and thereby sought to exploit the public's misunderstanding of science that influences policy.

Even some campaigns by environmental groups have reinforced technocratic narratives of climate science, facilitating technocratic "hegemonic discourses that stand as objective truths" (Dorsey, 2007, p.8). By supporting market mechanisms and technological fixes to climate change, such groups have shaped how we perceive the issue. The academy award winning 2006 documentary, An Inconvenient Truth, is an example of how this technocratic model affects the debate. The film buttresses the legitimacy of the IPCC, expert technology, and recommends market solutions for addressing climate change. By framing the issue in a technocratic fashion, the documentary influenced how the public perceived climate change and possible measures to address the issue ${ }^{2}$. A 2011 poll conducted by the Yale Climate and Energy Institute found that up to 58 percent of Americans favor a market-based solution to climate change, despite findings from the same poll indicating that only 60 percent of Americans were familiar with the legislative concept (Yale, 2011).

The correlation between political ideology and environmental beliefs in the US supports the

\footnotetext{
${ }^{1}$ James Wertsch's Mind as Action, outlines how the effects of cultural tools, or narratives, mediate the action of agents. Wertsch uses a sociocultural approach to explain the relationships between cultural and institutional tools and human action.

${ }^{2}$ According to a 2007 report Climate Change and Influential Spokespeople, nearly 90 percent of North Americans surveyed said they had become more aware of climate change after seeing the documentary An Inconvenient Truth. The same study found that 75 percent of North Americans polled said they were changing some habits after seeing the film.
} 
notion that science operates as a cultural tool. Confirmation bias seems to exist in the ways in which Americans assimilate climate science. According to a 2008 poll conducted by polling agency Gallup, only 41 percent of Republicans polled indicated that the effects of global warming had already begun, while 76 percent of Democrats polled indicated that the effects of global warming had already begun (Dunlap, 2008). The partisanship of opinion on climate change is even more pronounced among U.S. policymakers and political elites (Dunlap, 2008, p.1). It is clear that science, including idiosyncratic interpretations of it, can operate as narratives and influence perception.

The ideal of science to escape the influence of subjective beliefs helps give the scientific method its legitimacy as an informer of public policy. The science that informs the public and policymakers therefore has a responsibility to adhere to this ideal, and to avoid subjectivism and special interest. The political positions of politicians are partly shaped by different ethics, values, and beliefs - all of which are subjective. These values and beliefs have a place in policy discourse, but politicians and the general public, not science, are the appropriate actors to voice subjective opinion and make value-laden decisions. When politicians construct subjective narratives of science, they undermine objectivism, and weaken the basis for which science informs policy. In this way, the power of technocratic science stifles its efficacy.

\section{Manipulated Science}

Technocratic policy making has exacerbated an already dichotomized debate about whether climate change is caused by humans, or is naturally occurring. On the surface, it seems as if the debate is about the science underpinning climate change, but that is not entirely true. Because technocracy highlights scientific content, the current debate about the "science" underpinning climate change is fused with subjective opinions and political agendas. Subjective interests may influence what political actors may represent as science.

This artificial "scientific debate" about climate change is largely exclusive to the United States (Dorsey, 2011). The efforts of vested interests have created a debate over climate science instead of policy - where the real debate lies. For instance, shortly after the IPCC released its fourth assessment report in 2007, the American Enterprise Group, funded largely by American oil companies, sent out a slew of offers to prominent climate scientists offering up to $\$ 10,000$ if scientists would publish articles which elaborated on the uncertainty of the assessment report (Sample, 2007). Because science is given so much authority, dissidents find that challenging science is more effective than actually debating policy measures. These dissidents do not necessarily need to "win" a debate about climate science. As long as there is still a debate about the science of human caused climate change, contrarians have essentially bogged down the establishment of policy. If the public and policy makers cannot bolster conclusions with a high degree of certainty, because dissenting narratives distract them, forming policy will always be elusive.

The pseudo debate about climate science is reinforced in the halls of the U.S. Congress. The scientific "debate" about climate change has caused Congress, the members of which are not typically possessed of scientific backgrounds, to engage in a heated debate over the scientific findings of climate change. In debating a measure that would eliminate all U.S. funding to the 
IPCC, Republican Rep. Blaine Luetkemeyer posited that the IPCC scientists "have whipped up a global frenzy about a phenomenon which is statistically questionable" (Piltz, 2011, p.1). In response, Democratic Rep. Henry Waxman argued that the IPCC provides "objective and policy-neutral information" (Piltz, 2011, p.1). Regardless of which Congressmen represents the situation more fairly, the fact that the debate continues is ultimately more significant. By granting consensus and contrarian positions on science equal time in a "debate," Congress creates the impression of a balanced argument, and ignores the consensus of mainstream climate science. This insistence on "equal time," which is peculiar to the U.S. and can be a Federal Communications Commission requirement, is a mechanism of politics that allows politicians and special interests to mobilize contrarian science to support highly specific agendas.

The ways in which the scientific authority of a handful of skeptical scientists is used by vested interests illustrate the value of scientific authority in the discussion of climate change. Recent campaigns to undermine scientific consensus by various industry groups substantiate this notion. When science is given so much value in climate discourse, it undermines the public role. The public has difficulty engaging in what at times can be an esoteric discussion of complex scientific issues related to the climate. In this fashion, increasing science's role, and establishing a debate between different notions of science decreases the grounds on which deliberate or discursive democracy can exist ${ }^{3}$.

\section{Discussion and Research Implications}

There are no easy solutions to addressing the unbalanced roles of actors in the climate policy discourse. Reorganizing the role of science in the climate debate poses a large challenge to the status quo. Nevertheless, if science could be reorganized so that it were not so technocratic, the dead-end pseudo debate over science could be more effectively addressed. A scientific debate about political value and belief can be neither won nor lost. This research suggests that if the public could experience a larger role and act as an intermediary between science and policymakers, the debate about climate science could restore itself to a real debate about the merits of different policy options, not the mere existence of the phenomenon. In sum, if the roles of the public, policymakers, and science were better balanced, it would not place so much emphasis on science as an informer of policy. Science in its pure form is unsuitable to this task, and the public can help address this issue.

One way to address technocratic science is to increase the role of the public in policy discourses. This would diversify the voices that inform policy and to help restore the "scientific debate" to a policy debate by reinvigorating democracy. The role of experts does not necessarily have to drown out the public voice, for "expertise and democracy are not inherently adversarial concepts" (Lahsen, 2005, p.148). There will always be an important role for scientific experts in policy discussions of climate change, but, in order for policy

\footnotetext{
${ }^{3}$ Discursive democracy is characterized in John Dryzek's Discursive Democracy: Politics, Policy and Political Science as based on "inter-subjective discourse" between competent actors. Dryzek's discursive design for governance is modeled on the classical Aristotelian model of politics to include participatory involvement, communicative action, and critical theory.
} 
discourse to function, it must be in dialogue with the roles of other relevant actors like the public. In this regard, liberal political approaches such as the climate justice movement should be encouraging ${ }^{4}$. Grassroots environmental movements in the U.S. in the ' 60 s and '70s proved that the public is capable of participating significantly in the formation of environmental policy. Such a re-engagement would take the political pressure off science - a pressure, as current experience informs us, that science is not well equipped to manage.

Increasing the public's role also means that the public will bear more responsibility in discussions of climate change. The public must find a way to be a critical judge of science, and this research underpins the issues that arise when it is not. Indeed, it is important for the public and policymakers alike to distinguish between experts motivated by concealed and undisclosed funding and those pursuing objectivism. Scientists funded by oil companies and the fossil fuel industry for the sake of advancing special interests, have, instead of informing public policy, created counterproductive narratives of the issues. By gaining awareness of the interplay between narratives, perspectives, and action, the public can better judge science. The fact that U.S. Congress members opposing climate policy repeatedly call a small number of industry-funded scientists to address Congress about climate change is telling of how much weight expert scientific opinion carries, regardless of whether or not the expert adheres to scientific principles (Oreskes \& Conway, 2010). If the overplayed authority of science in a technocratic system is offset by an increased role for the public, the effectiveness of "expert" contrarian opinion may simultaneously diminish.

One tool for helping the public participate in policy decisions is the peer review process, which is designed to help consumers distinguish between well-grounded and dissenting science. Gaining access to the peer review process may be difficult for the public as peer reviewed science seems to deal with complicated issues and is highly technical. Some of the burden may rest on actors such as the media, which can help consumers assimilate technical and complicated information. Government also has a responsibility to build informed policy based on consensus science, and to not be misled by a circle of reappearing industry-funded experts. By being engaged, active and responsible, the government, the public, and the media, can reinforce each other's ability to judge competing scientific narratives.

\section{Conclusion}

A technocratic form of policy making has hampered the U.S.'s ability to address climate change because of the weaknesses exposed by unbalanced roles of science, the public, and the policymakers. The function and message of mainstream science can be obstructed by political pressure ${ }^{5}$. Policymakers have been seduced by the illusion of a scientific struggle that on many issues simply does not exist; thus they (intentionally or unintentionally) avoid

\footnotetext{
${ }_{5}^{4}$ See Bond \& Dorsey (2010) for a comprehensive outline of the climate justice movement.

${ }^{5}$ Science and scientists are susceptible to perversion from within, including grants, lucrative industry jobs, and long-term support from foundations and think tanks. For instance, Willie Soon, an eccentrically vocal climate skeptic who has often offered Congressional testimony, has reportedly received over \$1 million dollars from U.S. oil and coal companies over the past decade - it has been alleged that every new grant received by Soon from 2002 to 2011 was from oil and coal industries (Vidal, 2011).
} 


\section{I Macrothink}

Journal of Public Administration and Governance ISSN 2161-7104 2012, Vol. 2, No. 4

the value-laden policy debate about climate policy that is necessary to deal with the issue. The public role is tempered by an overgenerous genuflection to "science" and has not assimilated fully the cultural tools to allow the public to become better informed about the science of climate change.

There is still a need for scientific expertise in discussions of climate change. However, this role can be reorganized to be consistent with democracy and objectivism. The public's role clearly needs to be increased with respect to policy discourse if effective policy is to be produced and the entrenched arguments of expert-led science are to be transcended - for the public has the impetus which can bring about a real debate about climate policy. Only when all actors in the process have balanced roles can the United States' historic love of science be used as a productive force rather than becoming a stultifying, destructive lovesickness.

\section{Acknowledgement}

Thank you to Fulbright Canada and the American Killam Trusts for making this research possible.

\section{References}

Allegre, C., et al,. (2012, January 26). No Need to Panic About Global Warming. Wall Street Journal.

Bond, P., \& Dorsey, M. K. (2010). Anatomies of environmental knowledge and resistance: diverse climate justice movements and waning eco-neoliberalism. Journal of Australian Political Economy, (66), 286-316.

Byer, R. L. (2012, February 6). American Physical Society Responds. Wall Street Journal.

Climate Change and Influential Spokespeople (Rep.). (2007). Nielsen Company \& the Environmental Change Institute.

Dorsey, M. K. (2011, March 23). Climate justice on the road to Durban and beyond: movements below, paralysis above? Lecture presented at The Sustainability Series in Wrigley Hall Room 481, Tempe, Arizona.

Dorsey, M. K. (2007). Climate knowledge and power: Tale of skeptic tanks, weather gods, and sagas for climate (in)justice. Capitalism Nature Socialism, 18(2).

Dryzek, J. S. (1990). Discursive democracy: Politics, policy, and political science. Cambridge University Press.

Dunlap, R. E. (2008). Climate-Change Views: Republican-Democratic Gaps Expand(Rep.). Gallup.

Funtowicz, S., \& Ravetz, J. (1993). Science for the post-normal age. Futures, 25(7), 739-755.

Edwards, A. (1999). Scientific expertise and policy-making: The intermediary role of the public sphere. Science and Public Policy, 26(3).

Goldenberg, S. (2012, February 21). Climate scientist Peter Gleick admits he leaked 
Heartland Institute documents. The Guardian.

IPCC. (2011, May). Communications Strategy (Rep.). Retrieved April 12, 2012, from Intergovernmental Panel Climate Change website: http://ipcc.ch/meetings/session33/ipcc_p33_decisions_taken_comm_strategy.pdf

Lahsen, M. (2005). Technocracy, Democracy, and U.S. Climate Politics: The Need for Demaracations. Science, Technology \& Human Values, 30(1).

Oreskes, N., \& Conway, E. M. (2010). Merchants of Doubt: How a Handful of Scientists Obscured the Truth on Issues from Tobacco Smoke to Global Warming. Bloomsberry Press.

Oreskes, N. (2007) “The Scientific Consensus on Climate Change: How Do We Know We're Not Wrong?" in Climate Change. Joseph F. DiMento, Pamela Doughman, eds. MIT Press, pp. 66-98.

Piltz, R. (2011, February 19). House votes 244-179 to kill U.S. funding of IPCC. Climate Science Watch.

Sample, I. (2007, February 2). Scientists offered cash to dispute climate study. The Guardian.

Shellenberger, M., \& Nordhaus, T. (2004). The Death of Environmentalism (Rep.).

Trenberth, K. (2012, February 1). Check With Climate Scientists for Views on Climate.Wall Street Journal.

Vidal, J. (2011, June 28). Climate sceptic Willie Soon received \$1m from oil companies, papers show. The Guardian.

Wertsch, J. (1998). Mind as Action. Oxford University Press.

Yale Climate and Energy Institute, YCEI. (2011, February). Poll: Americans Support Strong Climate, Energy Policies [Press release]. Retrieved April 10, 2012, from http://climate.yale.edu/news/poll-americans-support-strong-climate-energy-policies

\section{Copyright Disclaimer}

Copyright reserved by the author(s).

This article is an open-access article distributed under the terms and conditions of the Creative Commons Attribution license (http://creativecommons.org/licenses/by/3.0/). 